\title{
EFFECT OF SOYBEAN LECITHIN ON FREEZABILITY AND FERTILIZING POTENTIALS OF BOVINE SPERMATOZOA
}

\author{
M.R. BADR; MARY G. ABD EL-MALAK; K.M. MOHAMMED and EBTIHAL A. \\ IBRAHIM
}

Artificial Insemination and Embryo Transfer Department, Animal Reproduction Research Institute, Haram, (P.O.B. 12556), Giza, Egypt. e-mail: magdybadr69@yahoo.com

\section{ABSTRACT}

\section{Received at: $29 / 3 / 2012$}

Accepted:22/4/2012
Soybean lecithin has been attracted increasing attention and has been used to replace egg yolk in the semen extender. In the present study, effect of soybean lecithin on bovine semen freezability and in vitro fertilizing potentials were evaluated. Semen was cryopreserved in tris-based extender supplemented with different soybean lecithin concentrations $(3,5,7,10$ and $20 \%$ ) vs $20 \%$ egg yolk (control). Semen post-thawing motility, viability and acrosomal integrity, DNA damage, enzymes leakage, total antioxidant activity (TAC), lipid peroxidation and in vitro fertilizing potentials were assessed. Current results indicated that addition of $7 \%$ soybean lecithin to semen extender significantly $(\mathrm{P}<0.05)$ improved post-thawing motility, viability and acrosomal integrity $(61.25 \pm 1.25 \%$, $172.25 \pm 5.53$ and $10.25 \pm 2.39 \%$, respectively) compared with control $(47.50 \pm 4.78 \%, 106.25 \pm 16.88$ and $22.00 \pm 1.47 \%$, respectively). At the same time, a significantly reduced $(\mathrm{P}<0.05)$ sperm DNA damage, tail length and tail moment of the cryopreserved semen $(1.48 \pm 0.27 \%, 2.08 \pm 0.36 \mu \mathrm{m}$ and $3.14 \pm 1.32$, respectively) compared with control $(3.31 \pm 0.17 \%, \quad 3.93 \pm 0.24 \mu \mathrm{m}$ and $13.09 \pm 1.38$, respectively). Moreover, extender containing 7\% soybean lecithin significantly $(\mathrm{P}<0.05)$ increased TAC $(0.47 \pm 0.04 \mathrm{~m} \mu / \mathrm{ml})$ and decreased lipid peroxidation (Malondialdehyde) of the cryopreserved spermatozoa $(9.18 \pm 1.47 \mathrm{nmol} / \mathrm{ml})$ with respect to the control $(0.19 \pm 0.02 \mathrm{m \mu} / \mathrm{ml}$, and $21.57 \pm 1.45 \mathrm{nmol} / \mathrm{ml}$, respectively). Additionally, $7 \%$ soybean lecithin significantly $(\mathrm{P}<0.05)$ improved in vitro fertilization rate, cleavage rate, morula and blastocyst development $\quad(54.14 \pm 6.21, \quad 52.81 \pm 3.32, \quad 27.49 \pm 2.78 \quad$ and $18.44 \pm 2.11 \%$, respectively) compared with the control $(35.10 \pm 3.23$, $31.75 \pm 5.52,12.2 \pm 4.08$ and $4.82 \pm 2.12 \%$, respectively). It was concluded that the addition of $7 \%$ soybean lecithin to the freezing extender improved freezability and enhanced in vitro fertilizing potentials of bovine spermatozoa through protection of DNA from deterioration and reduction of oxidative stress.

\footnotetext{
تأثير ليسيسين الصويا علي قابلية حيامن الأبقار للتجميد وقرتها الإخصابية معمليا مجدي رمضان بلر ، ماري جاد عبل الملاكك ، كامل مصطفي محد ، ابتهال عبل الله /بر/هيم

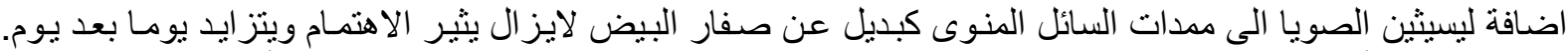
وحديثا ظهرت أنو اع جديدة من مددات السائل المنوي خالية من الإضافات الحيو انية (صفار البيض أو اللبن) وبالرغم من الئن
} 


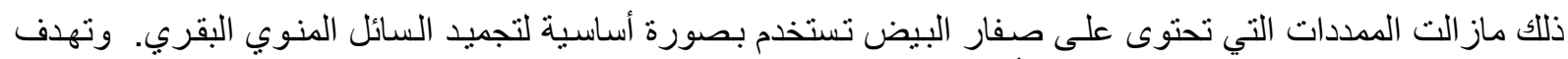

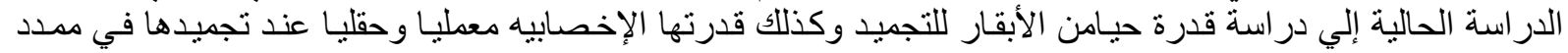

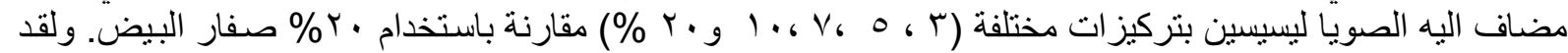

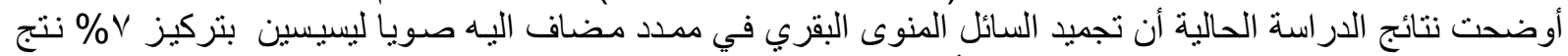

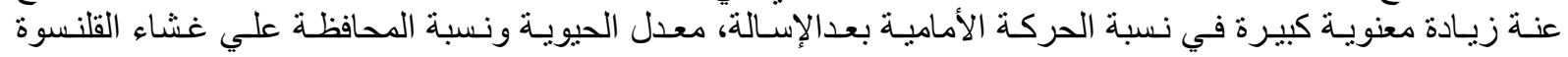

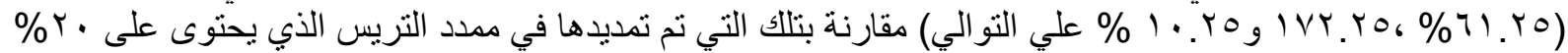

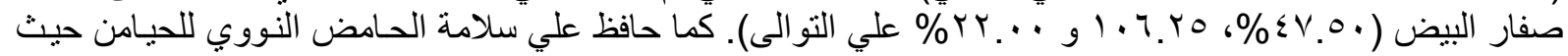

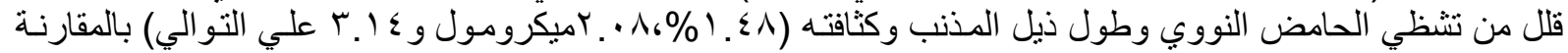

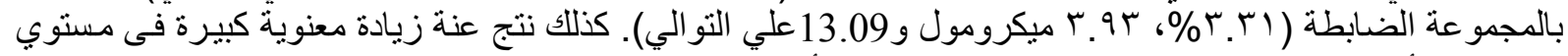

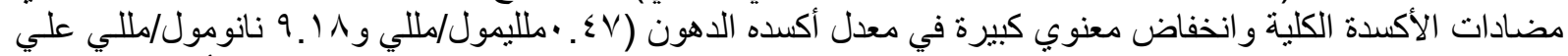

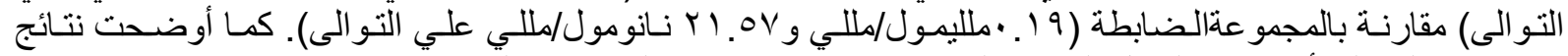

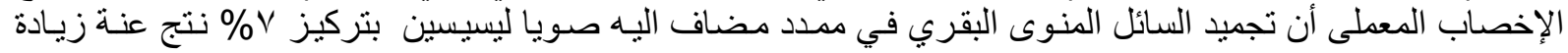

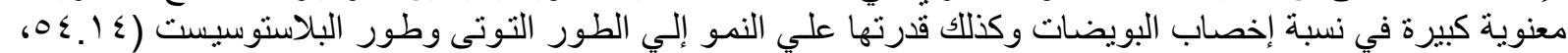

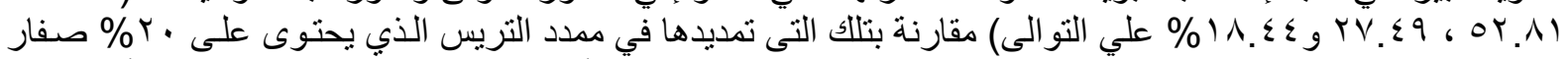

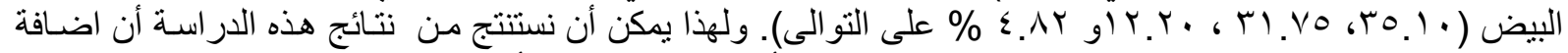

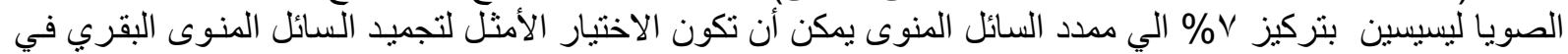

Key words: Soybean lecithin, semen cryopreservation, DNA integrity, IVF, antioxidant.

\section{INTRODUCTION}

Semen cryopreservation has profound effects on spermatozoa, many of which result in sublethal damage to the cells, and subsequent reduction of fertilizing ability. The sperm plasma membrane serves as the main physical barrier to the outside environment and is a primary site of freezethaw damage. Such damage includes membrane destabilization due to lateral lipid rearrangement (De Leeuw et al., 1990), loss of lipids from the membrane (Buhr et al., 1994 and Golal et al., 1998), and peroxidation of membrane lipids as a result of formation of reactive oxygen species (ROS) (Aitken 1995; Flesch and Gadella, 2000; Badr et al., 2010). These events can affect sperm motility, response to osmotic stress, and signaling pathways; therefore, the fertilizing ability is compromised (Holt, 2000). Defining causes of damage to sperm during cryopreservation is further complicated because the processing of semen for cryopreservation is not standardized and there is a wide variety of freezing diluents in use. Semen extender contain some forms of lipids, the most common being egg yolk lipids (Watson, 1995). Egg yolk, a common protectant in cryopreservation media, has been used for providing protection against cold shock in the cryopreservation of mammalian semen for over half a century (Gousset et al., 2004). However, there have been frequent arguments against the use of animal-originated ingredients, egg yolk, milk or even low density lipoprotein (LDL) extracted from egg yolk, one of which is the wide variability of composition that make it difficult to analyze the beneficial effects of a particular compound on sperm cryopreservation. Furthermore, they could introduce possible sanitary risks (viruses, bacteria and fungi), with the subsequent production of endotoxins capable of damaging the fertilizing capacity of spermatozoa (Bousseau et al., 1998; Jiang et al., 2007).

As one of phospholipids, lecithin (or phosphatidylchline) is distributed widely in plants and it plays an important role in the regulation of the physiological function of animal cells bio-membrane (Thun et al., 2002). Soy bean lecithin has similar ingredients to egg yolk used for protection of animal spermatozoa from cold shock in semen cryopreservation (Aires et al., 2003). It has been suggested that soybean lecithin may play a better protective role for spermatozoa than egg yolk during the 
cryopreservation process and therefore reduce the risk of introducing bacterial and mycoplasma into freezing extenders (Fukui et al., 2008). The main goal for the present study was to determine the effect of soybean lecithin as cryoprotective on bull spermatozoa, through investigating the quality parameters of the cryopreserved spermatozoa, DNA integrity, antioxidant activities and in vitro fertilizing potentials of frozen-thawed bull semen.

\section{MATERIALS and METHODS}

\section{Semen collection and processing:}

Semen samples were collected from six fertile bovine bulls. Only semen samples at least $70 \%$ initial motility and $800 \times 10^{6}$ sperm cells $/ \mathrm{ml}$ were used. After collection, semen samples were pooled, split into 6 portions and diluted at $30^{\circ} \mathrm{C}$ with Tris-based extender supplemented with different concentrations of soybean lecithin $(3,5,7,10$ and $20 \%)$ vs $20 \%$ egg yolk (control). The extended semen was cooled to $5^{\circ} \mathrm{C}$ throughout 60 minute in a cold cabinet. The cooled semen was loaded into $0.25 \mathrm{ml}$ French straws (IMV, L'Aigle, France), then suspended into liquid nitrogen vapor inside foam box before immersed into liquid nitrogen. Frozen semen straws were thawed in a water bath at $37^{\circ} \mathrm{C}$ for 30 second. Postthawing sperm motility, viability and acrosomal integrity were assessed according to Mohammed et al. (1998).

\section{Assessment of sperm DNA integrity:}

DNA integrity and the incidence of DNA strand breaks or fragmentation was detected using alkaline comet assay according to BoeHansen (2005). Briefly, DNA status of individual cells was determined by the neutral single cell gel electrophoresis (comet) assay. For this assay, frozen-thawed spermatozoa were diluted in phosphate buffer saline (PPS), embedded in agarose, followed by cell lysis, DNA decondensation, electrophoresis and DNA staining with $50 \mu 1$ of $20 \mu \mathrm{g} / \mathrm{ml}$ ethidium bromide (Sigma). The cells were then visualized by fluorescent microscopy. Intact nuclei in the comet assay appeared to have compact and brightly fluorescent heads; in contrast, strand breaks in damaged cells allow DNA migration during electrophoresis, and a tail of DNA could be seen behind the head, giving the appearance of a comet (Hughes et al., 1996). After subjecting spermatozoa to the comet assay, sperm nuclei were analyzed by computer software program.

\section{Biochemical analysis:}

Extra-cellular aspartate-aminotransferase (AST); alanine-aminotransferase (ALT) and alkaline phosphatase (ALP) enzymes leakage during cryopreservation was assessed spectrophotometrically according Tietz (1976) to evaluate the membrane stability of spermatozoa. Additionally, total antioxidant capacity and membrane lipid peroxidation was estimated by the end point generation of malondialdehyde (MDA) determined by the thiobarbituric acid (TBA) test, of the cryopreserved spermatozoa were measured as described by Cortassa et al. (2004).

\section{Evaluation of in vitro fertilizing potential of the treated semen:}

The fertilizing potentials of the treated semen were assessed using in vitro fertilization technology, as demonstrated by Totey et al. (1992). Three straws from each treatment were thawed in a water bath at $37^{\circ} \mathrm{C}$ for $30 \mathrm{sec}$. The most motile spermatozoa were separated by swim up technique in the fertilization medium, modified Tyrode's Albumin-LactatePyruvate (TALP) containing $6 \mathrm{mg} / \mathrm{ml}$ bovine serum albumin (BSA), for 1 hour as recorded by Parrish et al. (1988). The uppermost layer of the medium containing the most motile spermatozoa was collected and washed twice by centrifugation at 2000 rpm for 10 minutes. The sperm pellet was resuspended in the fertilization TALP medium containing $10 \mu \mathrm{g} / \mathrm{ml}$ heparin. After appropriate dilution, $2 \mu \mathrm{l}$ (final concentration $2 \times 10^{6}$ sperm cell $/ \mathrm{ml}$ ) of sperm suspension was added to the fertilization drops, containing in vitro matured oocytes. Gametes were coincubated in the fertilization drops under sterile mineral oil for 18 hour at $39^{\circ} \mathrm{C}$ in an atmosphere of $5 \% \quad \mathrm{CO}_{2}$ in air with 
maximum humidity. The inseminated oocytes were freed from extra cumulus cells and attached spermatozoa by gentle pipetting and then cultured in TCM-199 medium for seven days in the same previous conditions. The proportional of cleaved oocytes was recorded 48 hour after insemination and those developed to the morula and blastocyst stages were recorded at 5-7 day post-insemination.

\section{Statistical analysis:}

All data were analyzed by using Costat Computer Program (1986) Cottort Software, and were compared by the least significant difference least (LSD) at 5\% levels of probability. The results were expressed as means \pm SE.

\section{RESULTS}

The results presented in Table 1 revealed that, addition of soybean lecithin to the freezing extender improved the freezability of bull spermatozoa compared with the control semen in a dose-dependent trend. Addition of $7 \%$ soybean lecithin to semen extender, appeared to be the best concentration that increased $(\mathrm{P}<0.05)$ significantly the post-thawing sperm motility; viability index and maintained acrosomal integrity $\quad(61.25 \pm 1.25 \%$, $172.25 \pm 5.53$ and $10.25 \pm 2.39 \%$, respectively) compared to the control semen $(47.50 \pm 4.78 \%, \quad 106.25 \pm 16.88 \quad$ and $22.00 \pm 1.47 \%$, respectively).

Data regarding the effect of soybean lecithin addition to the freezing extender on the total antioxidant capacity (TAC) and lipid peroxidation of the cryopreserved semen which indicated by malondialdehyde ((MDA) are presented in table 2. In vitro provision of semen extender with $7 \%$ soybean lecithin significantly $(\mathrm{P}<0.05)$ increased the total antioxidant and diminished lipid peroxidation of the frozenthawed semen $(0.47 \pm 0.04 \mathrm{~m} \mu / \mathrm{ml}$, and
$9.18 \pm 1.47 \mathrm{nmol} / \mathrm{ml}$, respectively) compared with the control extender $(0.19 \pm 0.02 \mathrm{m \mu} / \mathrm{ml}$, and $21.57 \pm 1.45 \mathrm{nmol} / \mathrm{ml}$, respectively). Moreover, data presented in table 2 clarified that, addition of $7 \%$ soybean lecithin to the semen extender maintained sperm cell membrane integrity and this appeared through reduction of extracellular enzymes (AST, ALT and ALP) leakage (70.00 \pm 4.56 , $11.5 \pm 1.04$ and $14.65 \pm 2.79 \mathrm{U} / \mathrm{L}$, respectively) compared with the control extender $(106.00 \pm 5.95,23.00 \pm 2.48$ and $23.27 \pm 3.75 \mathrm{U} / \mathrm{L}$, respectively)

With respect to the effect of soybean lecithin addition to the freezing extender on the DNA integrity of the frozen-thawed bovine spermatozoa are demonstrated in Table 3. The present data indicated that, in vitro provision of semen extender with $7 \%$ soybean lecithin significantly $(\mathrm{P}<0.05)$ decreased the DNA fragmentation, tail length and tail moment of the frozen-thawed semen $(1.48 \pm 0.27 \%, 2.08 \pm 0.36 \mu \mathrm{m}$ and $3.14 \pm 1.32$, respectively) as compared with the control extender $\quad(3.31 \pm 0.17 \%$, $3.93 \pm 0.24 \mu \mathrm{m} \quad$ and $13.09 \pm 1.38$, respectively).

Data concerning the effect of replenishing of semen extender with soybean lecithin on the in vitro fertilizing potentials and embryo development are presented in tables 4 and 5 . The current results revealed that, addition of $7 \%$ soybean lecithin to the freezing extender had a positive effect $(\mathrm{P}<0.05)$ on the in vitro fertilization rate and embryo developmental rate compared with the control semen. When 7\% soybean lecithin was added to the freezing extender, a higher proportion of in vitro fertilized oocytes, cleavage rate, morula and blastocyst development $\quad(54.14 \pm 6.21, \quad 52.81 \pm 3.32$, $27.49 \pm 2.78$ and $18.44 \pm 2.11 \%$, respectively) compared with the control semen $(35.10 \pm 3.23, \quad 31.75 \pm 5.52, \quad 12.2 \pm 4.08$ and $4.82 \pm 2.12 \%$, respectively). 
Table 1: Effect of different soybean lecithin concentrations on bovine spermatozoa freezability.

\begin{tabular}{lcccc}
\hline \multicolumn{1}{c}{ Treatment } & $\begin{array}{c}\text { Pre-freeze } \\
\text { motility (\%) }\end{array}$ & $\begin{array}{c}\text { Post-thaw } \\
\text { motility (\%) }\end{array}$ & Viability index & $\begin{array}{c}\text { Acrosomal } \\
\text { integrity (\%) }\end{array}$ \\
\hline Control & $78.75 \pm 3.12^{\mathrm{a}}$ & $47.50 \pm 4.78^{\mathrm{b}}$ & $106.25 \pm 16.88^{\mathrm{b}}$ & $22.00 \pm 1.47^{\mathrm{a}}$ \\
\hline $3 \%$ soy lecithin & $78.75 \pm 1.25^{\mathrm{a}}$ & $53.75 \pm 2.39^{\mathrm{ab}}$ & $131.88 \pm 10.38^{\mathrm{b}}$ & $15.5 \pm 1.33^{\mathrm{ab}}$ \\
\hline $5 \%$ soy lecithin & $77.5 \pm 3.23^{\mathrm{a}}$ & $56.25 \pm 2.40^{\mathrm{ab}}$ & $140.5 \pm 12.04^{\mathrm{ab}}$ & $15.5 \pm 2.55^{\mathrm{ab}}$ \\
\hline $7 \%$ soy lecithin & $82.25 \pm 1.44^{\mathrm{a}}$ & $61.25 \pm 1.25^{\mathrm{a}}$ & $172.25 \pm 5.53^{\mathrm{a}}$ & $10.25 \pm 2.39^{\mathrm{b}}$ \\
\hline $10 \%$ soy lecithin & $81.25 \pm 2.39^{\mathrm{a}}$ & $51.25 \pm 5.54^{\mathrm{ab}}$ & $116.87 \pm 9.92^{\mathrm{b}}$ & $15.25 \pm 1.92^{\mathrm{ab}}$ \\
\hline 20\% soy lecithin & $80.00 \pm 2.04^{\mathrm{a}}$ & $48.75 \pm 3.75^{\mathrm{b}}$ & $113.00 \pm 7.72^{\mathrm{b}}$ & $20.25 \pm 2.93^{\mathrm{a}}$ \\
\hline
\end{tabular}

Means in the same column with different superscripts are significantly differ at $\mathrm{P}<0.0$

Table 2: Effect of different soybean lecithin concentrations on biochemical activity of bovine spermatozoa.

\begin{tabular}{lccccc}
\hline \multicolumn{1}{c}{ Treatment } & $\begin{array}{c}\text { AST } \\
(\mathrm{U} / \mathrm{L})\end{array}$ & $\begin{array}{c}\text { ALT } \\
(\mathrm{U} / \mathrm{L})\end{array}$ & $\begin{array}{c}\text { ALP } \\
(\mathrm{U} / \mathrm{L})\end{array}$ & $\begin{array}{c}\text { TAC } \\
(\mathrm{m} \mu / \mathrm{ml})\end{array}$ & $\begin{array}{c}\text { MDA } \\
(\mathrm{nmol} / \mathrm{ml})\end{array}$ \\
\hline Control & $106.00 \pm 5.95^{\mathrm{a}}$ & $23.00 \pm 2.48^{\mathrm{a}}$ & $23.27 \pm 3.75^{\mathrm{a}}$ & $0.19 \pm 0.02^{\mathrm{c}}$ & $21.57 \pm 1.45^{\mathrm{a}}$ \\
\hline $3 \%$ soy lecithin & $90.75 \pm 7.48^{\mathrm{ab}}$ & $17.75 \pm 1.25^{\mathrm{ab}}$ & $15.48 \pm 2.08^{\mathrm{b}}$ & $0.31 \pm 0.08^{\mathrm{b}}$ & $16.1 \pm 1.64^{\mathrm{ab}}$ \\
\hline $5 \%$ soy lecithin & $74.75 \pm 8.78^{\mathrm{bc}}$ & $15.25 \pm 2.75^{\mathrm{bc}}$ & $16.43 \pm 1.10^{\mathrm{b}}$ & $0.42 \pm 0.04^{\mathrm{a}}$ & $14.39 \pm 2.6^{\mathrm{bc}}$ \\
\hline $7 \%$ soy lecithin & $70.00 \pm 4.56^{\mathrm{c}}$ & $11.5 \pm 1.04^{\mathrm{c}}$ & $14.65 \pm 2.79^{\mathrm{b}}$ & $0.47 \pm 0.04^{\mathrm{a}}$ & $9.18 \pm 1.47^{\mathrm{c}}$ \\
\hline $10 \%$ soy lecithin & $100.25 \pm 0.55^{\mathrm{a}}$ & $22.25 \pm 1.49^{\mathrm{a}}$ & $18.55 \pm 1.34^{\mathrm{ab}}$ & $0.29 \pm 0.02^{\mathrm{b}}$ & $16.79 \pm 2.59^{\mathrm{ab}}$ \\
\hline $20 \%$ soy lecithin & $91.25 \pm 2.17^{\mathrm{ab}}$ & $21.00 \pm 1.47^{\mathrm{a}}$ & $19.9 \pm 1.38^{\mathrm{ab}}$ & $0.27 \pm 0.03^{\mathrm{b}}$ & $17.94 \pm 1.69^{\mathrm{ab}}$ \\
\hline
\end{tabular}

Means in the same column with different superscripts are significantly differ at $\mathrm{P}<0.05$

AST: Aspartate-aminotransferase ALT: Alanine-aminotransferase ALP: Alkaline phosphatase

TAC: Total antioxidant capacity MDA: Malondialdehyde

Table 3: Effect of different soybean lecithin concentrations on DNA integrity of bovine spermatozoa.

\begin{tabular}{lccc}
\hline \multicolumn{1}{r}{ Treatment } & DNA integrity $(\%)$ & Tail length $(\mu \mathrm{m})$ & Tail moment \\
\hline Control & $3.31 \pm 0.17^{\mathrm{a}}$ & $3.93 \pm 0.24^{\mathrm{a}}$ & $13.09 \pm 1.38^{\mathrm{a}}$ \\
\hline $3 \%$ soy lecithin & $2.06 \pm 0.11^{\mathrm{bc}}$ & $2.28 \pm 0.45^{\mathrm{ab}}$ & $4.80 \pm 1.22^{\mathrm{c}}$ \\
\hline $5 \%$ soy lecithin & $2.17 \pm 0.25^{\mathrm{bc}}$ & $2.38 \pm 0.20^{\mathrm{ab}}$ & $5.31 \pm 1.47^{\mathrm{bc}}$ \\
\hline $7 \%$ soy lecithin & $1.48 \pm 0.27^{\mathrm{c}}$ & $2.08 \pm 0.36^{\mathrm{b}}$ & $3.14 \pm 1.32^{\mathrm{c}}$ \\
\hline $10 \%$ soy lecithin & $2.34 \pm 0.16^{\mathrm{b}}$ & $2.63 \pm 0.15^{\mathrm{ab}}$ & $7.11 \pm 2.41^{\mathrm{bc}}$ \\
\hline $20 \%$ soy lecithin & $3.06 \pm 0.32^{\mathrm{a}}$ & $3.22 \pm 0.20^{\mathrm{ab}}$ & $10.05 \pm 1.72^{\mathrm{ab}}$ \\
\hline
\end{tabular}

Means in the same column with different superscripts are significantly differ at $\mathrm{P}<0.05$ 
Table 4: Effect of different soybean lecithin concentrations on the in vitro fertilizing potentials of bovine spermatozoa.

\begin{tabular}{lccccc}
\hline Treatment & $\begin{array}{c}\text { No. of } \\
\text { oocytes }\end{array}$ & $\begin{array}{c}\text { No. of } \\
\text { Penetrated } \\
\text { oocytes }\end{array}$ & $\begin{array}{c}\text { Penetration } \\
\text { rate }(\%)\end{array}$ & $\begin{array}{c}\text { No. of } \\
\text { fertilized } \\
\text { oocytes }\end{array}$ & $\begin{array}{c}\text { Fertilization } \\
\text { rate }(\%)\end{array}$ \\
\hline Control & 87 & 54 & $63.07 \pm 8.34^{\mathrm{a}}$ & 31 & $35.10 \pm 3.23^{\mathrm{b}}$ \\
\hline $3 \%$ soy lecithin & 75 & 49 & $65.03 \pm 1.72^{\mathrm{a}}$ & 30 & $41.47 \pm 5.42^{\mathrm{ab}}$ \\
\hline $5 \%$ soy lecithin & 63 & 40 & $63.62 \pm 5.14^{\mathrm{a}}$ & 28 & $43.84 \pm 5.63^{\mathrm{ab}}$ \\
\hline $7 \%$ soy lecithin & 84 & 62 & $73.55 \pm 3.66^{\mathrm{a}}$ & 56 & $54.14 \pm 6.21^{\mathrm{a}}$ \\
\hline $10 \%$ soy lecithin & 71 & 46 & $63.41 \pm 4.13^{\mathrm{a}}$ & 33 & $46.03 \pm 3.44^{\mathrm{ab}}$ \\
\hline $20 \%$ soy lecithin & 63 & 43 & $68.19 \pm 6.27^{\mathrm{a}}$ & 22 & $34.71 \pm 2.28^{\mathrm{b}}$ \\
\hline
\end{tabular}

Means in the same column with different superscripts are significantly differ at $\mathrm{P}<0.05$

Table 5: Effect of different soybean lecithin concentrations on the bovine embryo development in vitro.

\begin{tabular}{lcccc}
\hline \multicolumn{1}{c}{ Treatment } & $\begin{array}{c}\text { No. of } \\
\text { oocytes }\end{array}$ & $\begin{array}{c}\text { Cleavage rate } \\
\text { No. }(\%)\end{array}$ & $\begin{array}{c}\text { Morula stage } \\
\text { No. }(\%)\end{array}$ & $\begin{array}{c}\text { Blastocyst stage } \\
\text { No. }(\%)\end{array}$ \\
\hline Control & 83 & $26(31.75 \pm 5.52)^{\mathrm{b}}$ & $10(12.2 \pm 4.08)^{\mathrm{b}}$ & $4(4.82 \pm 2.12)^{\mathrm{c}}$ \\
\hline $3 \%$ soy lecithin & 94 & $39(41.67 \pm 1.28)^{\mathrm{ab}}$ & $16(16.59 \pm 3.16)^{\mathrm{ab}}$ & $10(9.42 \pm 1.09)^{\mathrm{bc}}$ \\
\hline $5 \%$ soy lecithin & 70 & $32(45.32 \pm 5.39)^{\mathrm{ab}}$ & $13(18.85 \pm 2.99)^{\mathrm{ab}}$ & $9(12.83 \pm 1.79)^{\mathrm{ab}}$ \\
\hline $7 \%$ soy lecithin & 89 & $47(52.81 \pm 3.32)^{\mathrm{a}}$ & $24(27.49 \pm 2.78)^{\mathrm{a}}$ & $16(18.44 \pm 2.11)^{\mathrm{a}}$ \\
\hline $10 \%$ soy lecithin & 88 & $36(40.97 \pm 1.52)^{\mathrm{b}}$ & $15(16.35 \pm 3.92)^{\mathrm{ab}}$ & $7(7.28 \pm 3.03)^{\mathrm{bc}}$ \\
\hline $20 \%$ soy lecithin & 83 & $29(34.87 \pm 8.93)^{\mathrm{b}}$ & $7(8.3 \pm 2.55)^{\mathrm{b}}$ & $4(3.53 \pm 1.73)^{\mathrm{c}}$ \\
\hline
\end{tabular}

Means in the same column with different superscripts are significantly differ at $\mathrm{P}<0.05$

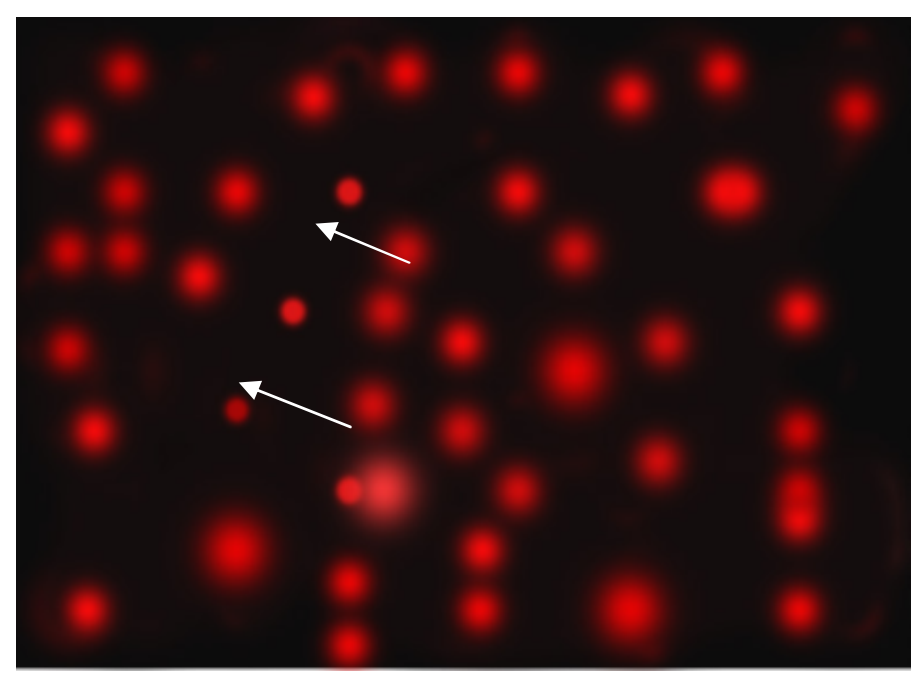

Fig 1: Bovine spermatozoa cryopreserved in tris-7\% soybean lecithin. The single cell gel electrophoresis (comet) assay showed reduction in the DNA fragmentation as represented by a limited amount of DNA present in the comet tail. 


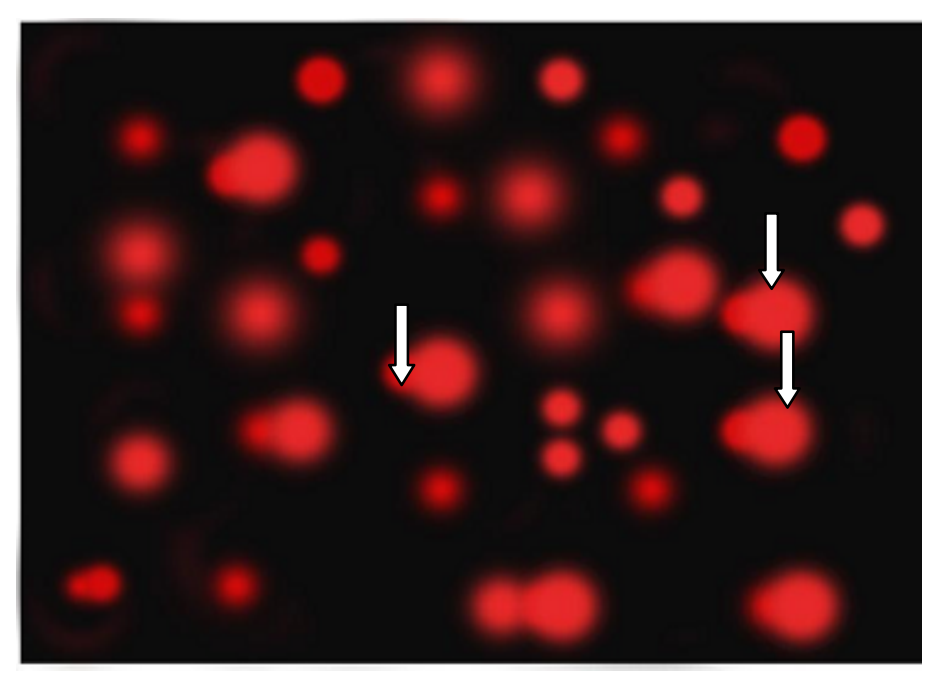

Fig 2: Bovine spermatozoa cryopreserved in tris-egg yolk extender. The single cell gel electrophoresis (comet) assay showed increased in the DNA fragmentation as represented by an increasing amount of DNA present in the comet tail.

\section{DISCUSSION}

In the present study, freezing extender supplemented with $7 \%$ soybean lecithin could provide better cryoprotective action for bovine spermatozoa during cryopreservation compared with control group $(20 \%$ egg yolk). These results are in accordance with the previous reports in the cryopreservation of bovine (Moussa et al., 2002 and Amirat et al., 2005), buffalo (Badr 2008) and sheep (Fukui et al., 2008) semen. Contrary, other researchers reported that the cryoprotective effect of soybean lecithin extenders on bovine sperm freezability was similar or slightly inferior to that of $20 \%$ egg yolk extender (Aires et al., 2003). The precise mechanism by which soybean lecithin protects spermatozoa during cryopreservation remains unclear. It was generally accepted that cold shock and cryodamage might impair the physiological function of spermatozoa membrane due to the change of the lipid composition of its bilayer and the fluidity of the plasma membrane during freeze-thawing process as a result of formation ROS (Johnson et al., 2000). Excessive generation of ROS negatively affect the fluidity of sperm plasma membrane and integrity of DNA in the sperm nucleus (Cocuzza et al., 2007). The beneficial effect of soybean lecithin extender on the sperm function may be attributed to the ability of the lecithin to maintain the integrity of cell membranes, facilitating the movement of fluids inside and outside the cell; and without lecithin cell membranes would harden and would no longer stay semi-permeable (Zeisel, 2000). It is believed that phospholipids from egg yolk or soybean lecithin might integrate with sperm membrane to form a protective film against the formation of lethal intracellular ice crystal and protect the sperm membrane from mechanical damage during freeze-thawing process (Quinn et al., 1985). These beneficial effect of soybean lecithin dose dependent on plasma membrane stability leads to reduction of extracellular enzymes leakages (AST, ALT and ALP) which appeared clearly in our findings mainly at concentration of $7 \%$. Additionally, soybean lecithin could play a protective role for sperm during cryopreservation due to its low viscosity and less debris which enhance the sperm motion characteristics and fertilizing ability, compared with egg yolk which provided higher viscosity and the presence of particulate debris in extenders (Van Wagtendonk-de Leeuw et al., 2000).

In a way, soybean lecithin is also thought as a better emulsifier that might promote cryoprotectants to distribute uniformly and 
reduce its local concentration, which led to relieve the toxicity of cryoprotectants during the freeze-thawing process (Trotta et al., 2002). Moreover, soybean lecithin might reduce the cholesterol/phospholipids ratio of sperm cell membranes by permeating into the sperm membrane, so capacitation like changes during the freezing process were restrained to improve the fertilizing ability of frozen-thawed spermatozoa (GalantinoHomer et al., 2006). The present results evidently revealed that soybean lecithin decreased significantly membrane lipid peroxidation, throughout reduction of malondialdehyde (MDA) production and increased total antioxidant capacity (TAC) in the frozen-thawed spermatozoa that maintain a suitable level of ROS which play a significant role in many physiological processes of the sperm such as capacitation, hyper-activation and sperm-oocyte fusion (Sies, 1993; Lewis et al., 1995). However, ROS must be continuously inactivated to keep only a small amount necessary to maintain normal cell function, as a result the excessive generation of ROS in semen can cause damage to sperm that increased by extruding of cytoplasm during the maturation process which is the major source of antioxidants. Therefore, the improved freezability and in vitro fertilizing potentials of the semen that extended in soybean lecithin extender may be attributed to the ability of the lecithin to protect the spermatozoa from the destructive effects of oxidative stress during cryopreservation (Chatterjee and Gagnon, 2001). Additionally, soybean lecithin may act as a stabilizer and protectant of proteins and cell membranes, whose fluidity decreases during temperature downshift. This may emphasize the current results which indicated that soybean lecithin provision to the freezing extender diminished the enzymes leakage.

Furthermore, the beneficial effect of soybean lecithin extender on semen cyropreservation may be attributed to the high concentration of linoleic acid in its constituent, which is the precursor of prostaglandin E. Addition of prostaglandin E to the semen extender increassed the life span of the spermatozoa and the cleavage rate of the inseminated oocytes (Kolev and Dimov 1998). Accordingly, in our results, post-thaw motility and viability index appeared significantly higher $(\mathrm{P}<0.05)$ in soybean additive diluent pariculary at $7 \%$ than $20 \%$ egg yolk addition.

In conclusion, the present study provides novel evidence that addition of $7 \%$ soybean lecithin to the freezing extender improved freezability and enhanced in vitro fertilizing potentials of bovine spermatozoa through protection of DNA from deterioration, reduction of the oxidative stress. We suggest that consistent with quality standards that should be required for cryoprotectant extender, soy lecithin-based extender in recommended dose $(7 \%)$ is a viable alternative to conventional egg-yolkbased freezing diluents for cryopreserving of bovine bull spermatozoa.

Acknowledgement: The authors greatly acknowledge to colleague prof. Dr. Hani Hassan for his valuable and privileged role in the comet assay.

\section{REFERENCES}

Aires, V.A.; Hinsch, K.D.; MuellerSchloesser, F.; Bogner, K.; MuellerSchloesser, S. and Hinsch, E. (2003): In vitro and in vivo comparison of egg yolk-based and soybean lecithin-based extenders for cryopreservation of bovine semen. Theriogenology, 60: 269-279.

Aitken, R.J. (1995): Free radicals, lipid peroxidation and sperm function. Reprod. Fertil. Dev., 7: 659-668.

Amirat, L.; Anton, M.; Tainturier, D.; Chatagnon, G.; Battut, I. and Courtens, J.L. (2005): Modification of bull spermatozoa induced by three extenders:Biociphos, Low denisity lipoprotein and Triladyl, before, during, and after freezing and thawing. Reproduction, 129: 535-543.

Badr, M.R. (2008): Cryopreservation of buffalo spermatozoa in soy lecithinbased extenders. Assiut Vet. Med. J., 54 (116): 272- 284 . 
Badr, M.R.; Mary G. Abd El- Malak and Hassan, H.M. (2010): Effect of trehalose on cryopreservation, oxidative stress and DNA integrity of buffalo spermatozoa. J. Reproduction and infertility, 1 (2): 50-57.

Boe-Hansen, G.B. (2005): Hydrogen peroxide alters the physical state and function of the plasma membrane of pulmonary artery endothelial cells. Journal of Cellular Physiology, 20: 362-374.

Bousseau, S.; Brillard, J.P.; Guienne, B.M.L.; Guérin, B.; Camus, A. and Lechat, M. (1998): Comparison of bacteriological qualities of various egg yolk sources and the in vitro and in vivo fertilizing potential of bovine semen frozen in egg yolk or lecithin based diluents. Theriogenology, 50: 699-706.

Buhr, M.M.; Curtis, E.F. and Kakuda, N.S. (1994): Composition and behavior of head membrane lipids of fresh and cryopreserved bull sperm. Cryobiology, 31: 224-238

Chatterjee, S. and Gagnon, C. (2001): Production of reactive oxygen species by spermatozoa undergoing cooling, freezing and thawing. Mol. Reprod. Dev.; 59: 451-458.

Cocuzza, M.; Sikka, S.C.; Athayde, K.S. and Agarwal, A. (2007): Clinical relevance of oxidative stress and sperm chromatin damage in male infertility: An evidence based analysis. Int. Braz J. Urol. Vol. 33 (5): 603-621.

Cortossa, S.; Aon, M.A.; Waston, R.L. and O'Rourke, B. (2004): A mitochondrial oscillator dependent on reactive oxygen species. Biopysic. J, 87: 20602073.

Costat Computer Program Copyright (1986): Version 3.03 copyright Cottort Software.

De Leeuw, F.E.; Chen, H.C.; Colenbrander, B. and Verkleij, A.J. (1990): Coldinduced ultrastructural changes in bull and bull sperm plasma membranes. Cryobiology, 27: 171-183

Flesch, F.M. and Gadella, B.M. (2000): Dynamics of the mammalian sperm plasma membrane in the process of fertilization. Biochim Biophys Acta, 1469: 197-235.

Fukui, Y.; Kohno, H.; Togari, T.; Hiwasa, M. and Okabe, K. (2008): Fertility after artificial insemination using a soybeanbased semen extender in sheep. J. Reprod. Dev. 54: 286-289.

Galantino-Homer, H.L.; Zeng, W.X.; Megee, S.D.; Dallmever, $M$. and Voelk, D. (2006): Effect of 2-hydroxypropylbeta-cyclodextrin and cholesterol on porcine sperm viability and capacitation status following cold shock or incubation. Mol. Reprod. Dev.; 73 (5): 638-650.

Golal, R.L.; Georgie, R.K.; Tuli, R.K.; Dixit, V.P. and Chand, D. (1998): Lipid peroxidation during freeze processing of washed buffalo (Bubalus bubalis) spermatozoa. Annals of Biology, 14 (2): 207-210.

Gousset, K.; Tsvetkova, N.M.; Crowe, J.H. and Tablin, F. (2004): Important role of raft aggregation in the signaling events of cold-induced platelet activation. Biochim Biophys Acta 1660: 7-15.

Holt, W.V. (2000): Basic aspects of frozen storage of semen. Anim Reprod Sci., 62: 3-22.

Hughes, C.M.; Lewis, S.E.; McKelveyMartin, V.J. and Thompson, W. (1996):

A comparison of baseline and induced DNA damage in human spermatozoa from fertile and infertile men, using a modified comet assay. Mol. Hum. Reprod., 2: 613- 619.

Jiang, Z.L.; Li, Q.W.; Hu, J.H.; Li, W.Y.; Zhao, H.W. and Zhang, S.S. (2007): Improvement of the quality of boar cryopreservation semen by supplementing with low density lipoprotein in diluents. Cryobiology, 54: 301-304.

Johnson, L.A.; Weitze, K.F.; Fiser, P. and Maxwell, W.M. (2000): Storage of boar semen. Anim. Reprod. Sci. 62:143172.

Kolev, S.I. and Dimov, K. (1998): Influence of synthetic $\mathrm{PGF}_{2}$ alpha and oxytocin on life time of ram's spermatozoa with 
and without sperm plasma at $46^{\circ} \mathrm{C}$. Bulgarian J. Agr. Sci., 4: 6, 831-835.

Lewis, S.E.; Boyle, P.M.; McKinney, K.A.; Young, I.S. and Thompson, W. (1995): Total antioxidant capacity of seminal plasma is different in fertile and infertile men. Fertil Steril. Oct; 64(4): 868-70.

Mohammed, K.M.; Ziada, M.S. and Darwish, G.M. (1998): Practical trials for freezing semen of buffalo and Friesian bulls: Effect of various regimens of freezing, different milk extenders and types of straws packages on postthawing semen characters. Assiut Vet. Med. J.; 39 (77): 70-93.

Moussa, M.; Martinet, V.; Trimeche, A.; Tainturier, D. and Anton, M. (2002): Low density lipoproteins extracted from hen egg yolk by an easy method: cryoprotective effect on frozen-thawed bull semen. Theriogenology, 57: 1695-1706.

Parrish, J.J.; Susko-Parrish, J.; Winer, M.A. and First, N.L. (1988): Capacitation of bovine sperm by heparin. Biol. Reprod.; 38: 1171-1180.

Quinn, P.J. (1985): A lipid-phase separation model of low-temperature damage to biological membranes. Cryobiology, 22: 128-146.

Sies, H. (1993): Strategies of antioxidant defense. Eur J Biochem; 215: 213-.
Thun, R.; Hurtado, M. and Janet, F. (2002): Comparison of Biociphos-Plus ${ }^{\circledR}$ and TRIS-egg yolk extender for cryopreservation of bull semen. Theriogenology, 57: 1087-1094.

Tietz, N.W. (1976): Fundamentals of clinical chemistry. W.B. Saunders Company, Philadelphia.

Totey, S.M.; Singh, G.; Taneja, M.; Pawshe, C.H. and Talwar, G.P. (1992): In vitro maturation, fertilization and development of follicular oocytes from buffalo (Bubalus bubalis). J. Reprod. Fertil.; 95: 597-607.

Trotta, M.; Pattarino, F. and Ignoni, T. (2002): Stability of drug-carrier emulsions containing phosphatidylcholine mixtures. Eur. J. Pharm. Biopharm., 53: 203-208.

Van Wagtendonk-de Leeuw, A.M.; Haring, R.M.; Kaal-Lansbergen, L.M.T.E. and Den Daas, J.H.G. (2000): Fertility results using bovine semen cryopreserved with extenders based on egg yolk and soy bean extract. Theriogenology, 54: 57-67.

Watson, P.F. (1995): Recent developments and concepts in the cryopreservation of spermatozoa and the assessment of their post-thawing function. Reprod Fertil Dev., 7: 871-891.

Zeisel, S.H. (2000): Cholin: An essential for humans. Nutrition, 16: 669. 